Ardoin, P. J. and Grady, D. (2006) The Politics of Electricity Restructuring Across the American States: Power Failure and Policy Failure, State and Local Government Review, 38(3): 165-175. Published by Sage (ISSN: 1943-3409).

\title{
The Politics of Electricity Restructuring Across the American States: Power Failure and Policy Failure
}

\begin{abstract}
While the broad purpose of this research is to provide an improved understanding of general state policy innovation, we develop and test a model of policy innovation which examines the factors that influence the probability of a state restructuring its electric utility policies. The results of our model of electric restructuring generally support our hypotheses and more broadly the literature regarding policy innovation. Our findings indicate economic interests continue to represent a key factor in understanding the policy choices of state legislatures. States which faced high energy costs were most likely to look for opportunities to reduce those costs. Second, we find state legislatures with the greatest resources and expertise were quickest to explore and adopt policy innovations in response to their high energy costs. Third, states where the general policy preferences of those in power favored deregulation (Republicans) were also more likely to restructure. Finally, we note it is interesting that a policy innovation which many believe to have failed so miserably was most likely to be adopted by the most professional (sophisticated) legislatures.
\end{abstract}


All states have an energy policy. In some states the political leadership explicitly lays out a strategy for diversifying its energy supply options and ensuring a reliable, affordable supply. In others, the policy is implicit in that it reflects what state policy leaders choose not to do. In the most comprehensive sense, a state's energy policy is the result of decisions state leaders make or do not make on supplying electricity to businesses and homes and how it encourages or discourages various transportation fuel supply options. In this investigation, we focus on the first sphere of activity (electricity policy) since transportation fuel decisions operate in an entirely different policy sphere. Electricity policy engages fundamental issues of federalism, the regulatory process, interest group politics, and executive/legislative politics. Thus it provides an interesting lens through which to examine the dynamics of state politics.

While typically not headline grabbing in its saliency, how a state handles its electricity policy is inextricably linked with its economic development prospects and its environmental quality. By itself, the energy industry is over $7 \%$ of the nation's gross domestic product or approximately $\$ 558$ billion in expenditures. (Energy Information Administration, 2003) Electricity stakeholders are major economic and political players across the states (Thomas and Hrebenar 2004). The price of electricity historically was regulated by the states and, in most states still is; thus, it is the focus of tremendous interest by the state’s business establishment. Furthermore, since many large economic sectors such as manufacturing, mining, and chemical processing are energy intensive enterprises, and since these industries are highly competitive, the cost of electricity is a major factor in determining expansion and/or relocation. As if this were not enough to make energy policy an important political issue, the primary sources of air pollution and global warming ( $\mathrm{NOx}, \mathrm{SO}_{2}$, and $\mathrm{CO}_{2}$ ) are directly tied to burning coal for electricity production and burning petroleum products in vehicles (Freese 2003; Rosenbaum 2003; Timney 2005). Therefore, the quality of our nation's air and water is directly tied to decisions on energy issues. Furthermore, since we have not identified a safe way to dispose of nuclear waste and since most non-military nuclear waste is the result of generating electric power, nuclear waste disposal is a highly contentious political issue within states, among states, and between states and the national government (Rosenbaum 2003). Thus, state decision makers, business and industry leaders, and the environmental community are all intensely attuned to the ebbs and flows of energy decisions made by a myriad of powerful actors.

Much of the activity in this policy area occurs away from the glare of public scrutiny and reflects typical regulatory relationships among traditional political elites - utility commissions, regulated utility companies, and large energy consumer groups (Chubb 1983; Gormley 1983). Three decades ago, political turmoil in the Middle East and the formation of OPEC thrust energy issues to the forefront of public attention as drivers waited in line at gas pumps and President Carter went on national television in 
a cardigan sweater to ask the American people to conserve energy by turning their thermostats down. More recently, rolling blackouts in California, the collapse of the world's largest energy trading company (Enron), the power outage of August 2003 and yet again political turmoil in the Middle East and \$60 a barrel oil prices have thrust energy issues on the front pages of major newspapers and to the front of the policy agenda across the states and in the Nation's capital. Added to the current political context is the most dramatic restructuring of the electricity market since its development in the 1930s.

\section{$\underline{\text { Statutory Context of Electricity Regulation and Deregulation }}$}

During the last half of the 1990s the market for electricity underwent a transformation that challenged the traditional understanding of the role utility companies, state regulatory entities, and national policy makers play in providing reliable and affordable electricity to customers. In order to understand the current political context confronting the utility companies, regulatory bodies, legislatures, and consumers, it is necessary to review a brief history of electricity's legal and economic environments (Energy Information Administration, 1997).

For almost forty years following the passage of the Public Utility Holding Company Act (PUCHA) in 1935, the statutory scene in electric utility regulation was tranquil. However, during the 1970s things began to change. Market conditions within the electric industry shifted dramatically in response to the 1973 Arab oil embargo, the financial collapse of utility stocks following Consolidated Edison's dividend freeze in 1974, and the instability of the political situation in the Middle East manifest by the Iranian revolution of 1978 . In response to these threats to the stability of the electricity market, Congress passed the Public Utilities Regulatory Policies Act of 1978 (PURPA) with the intent of ensuring greater energy security. Its effect was to open the door to competition in the electricity supply market by requiring utility companies to purchase electricity from independent generating facilities (known as qualifying facilities) that used cogeneration technology or which generated less than 50 megawatts using renewable technologies.

In 1992, the Energy Policy Act (EPAct) opened up the wholesale market for electricity to nonutility generators of electricity. A new class of electricity suppliers was created - exempt wholesale generators -- who where allowed to compete for the right to sell electric power. Further, Congress mandated that utilities provide wholesale power transmission services to third parties at cost-based rates, even if doing so caused them to expand their transmission capacity. Finally, the Federal Energy Regulatory Commission (FERC) was given the responsibility for implementing open access to the transmission grid as a way of fostering competition in the electricity wholesale market. 
Following the 1992 legislation, FERC Order 888 and Order 2000 were issued with the intent of fundamentally transforming the utility industry from a regulated industry to an open marketplace where electricity is generated and sold on the wholesale market much like any other commodity. FERC Order 888 issued in 1996 created an open access policy requirement for all transmission owning entities under its jurisdiction. The Order required transmission owners to provide equal access to all market participants on a first come, first served basis. In order to facilitate this open access rule, FERC required that the vertically integrated utilities (typically investor owned utilities, IOUs, with generation, transmission, and distribution capability) to functionally separate their distribution and transmission units. In essence, Order 888 shifted the function of the transmission grid from serving the transmission owners' interests (serving their own customers) to creating a common carrier system for electricity that is open to market use - much like natural gas. As in most intergovernmental policy arrangements, FERC is responsible for regulating the interstate sale (transmission) of electricity and the rules for competition (antitrust regulation) while states are responsible for intrastate market (retail and wholesale) entry and pricing. Therefore, once the rules changed at the federal level, states were free to respond by opening the intrastate market.

In 1996, California and Rhode Island took quick advantage of this opportunity and passed landmark legislation to restructure their electric power industries in order to give their residents the right to choose their electricity supplier. ${ }^{2}$ Very rapidly many states followed suit so that by 1998, twety-four states had passed some form of utility restructuring legislation. Then just as rapidly the momentum behind restructuring quickly faded primarily due to events that unfolded in California over 2000-2001. Rolling blackouts occurred during peak summer demand periods, electric rates jumped from \$.08 a kWh to $\$ .38 \mathrm{kWh}$, and one of the state's major electric companies, Pacific Gas and Electric, declared bankruptcy. The grand promises of open market competition where prices would be driven down for the majority of rate payers, has been realized in few if any states as of mid-2006. And, while some restructured states such as Pennsylvania, New York, and New Jersey have not experienced the disaster of California, the jury remains out regarding the impact of retail competition on industrial rates in those states (Adams, 2006), Clearly, policy innovation had failed at least in one state and no state has restructured or even continued the examination of restructuring since. ${ }^{3}$ Summarizing the situation, Timney (2005) writes:

A regulated system that most ordinary citizens thought worked well enough had been abandoned in favor of a wild and volatile free market that served the interests of a few large companies at the expense of small businesses and retail users in the state. There seemed to be a lot of losers in the state and only a few winners - most prominent of which were the energy trading companies that had lobbied aggressively for the plan in the first place. (p. 76) 
While much has been written on the causes of California's policy failure (eg., Borenstein 2002; Hirst 2001; Timney 2005), relatively few analyses have been conducted on the reasons for the policy innovation to take hold so rapidly in so many states. Our intention is to review what literature exists on the topic, derive a model that explains policy adoption, and test it to assess if it comports with other policy diffusion studies or if it departs from previous efforts given the uniqueness of this issue.

\section{Deciding to Deregulate}

Having laid the groundwork for the rise and precipitous fall of electricity restructuring, our discussion will now move to a review of the various factors hypothesized to influence a state's probability of adopting policies aimed at energy deregulation. While state legislatures are the ultimate decision makers regarding energy deregulation there are several factors within legislatures and numerous players in this policy process that we argue play a significant role. Much of the literature (Ando and Palmer 1998; Andrews 2000; Berry 1979; Gormley 1983; Joskow 2000; Ka and Teske 2002; Steiner 2004; Teske 2004; White 1996) on energy deregulation suggests the presence and growth of regional price disparities laid the foundation for the waves of energy deregulation which began in 1996. Price disparities and resultant calls for change led to action from numerous political drivers - specifically, interest groups and other institutional forces. With this in mind we examine the impact of industrial-residential price disparities, the relative cost of energy in each state, interest group influences, the partisanship of the state legislature, and the selection process of Public Utility Commissions (PUCs) on the likelihood of a state adopting energy deregulation policies. Finally, we conclude our theoretical section with a discussion of the potential influence of regional diffusion on policy innovation regarding energy deregulation

\section{Industrial/Residential Price Ratios}

The disparity in electricity prices, and its inherent saliency to consumers, is noted by many scholars as the driving force behind deregulation (Andrews 2000; Borenstein 2002; Borenstein and Bushnell 2000; Joskow 1997; Ka and Teske 2002; Moyer 1993; Steiner 2004; Teske 2004). Borenstein and Bushnell (2000) posit that the price gap originated with "uneconomic PURPA contracts and nuclear power investments” (Borenstein and Bushnell, 2000, 47), whereas Ka and Teske (2002) attribute the initial saliency to the Arab oil embargo. Whether attributed to PURPA contracts, nuclear investments, or to the oil-crisis of 1973 , the widening price gap is purported to be a major factor in restructuring. ${ }^{4}$

A simple means of understanding these differences is to examine the industrial sector price for energy per $\mathrm{kWh}$ as a percentage of the residential sector price for energy per $\mathrm{kWh}$. This simple computation provides a ratio of the relative cost industries pay as compared to residential users. As the 
ratio increases, this indicates the industrial sector pays relatively more in comparison to the residential sector. An examination of this ratio for the year 1996 indicates substantial variation in the price ratios throughout the United States with industrial users in Tennessee (.77) paying relatively equal prices to residential users and industrial users in New York (.40) paying relatively less than residential users. ${ }^{5}$

While residential and industrial users are both represented by interest groups interested in limiting energy costs, industrial electricity user groups represent the more powerful interests in energy policy choices, as they are well organized and have direct incentives to participate in the energy policy process. Considering the general belief by industries that deregulation would decrease their costs, we hypothesize that industry in states with higher residential-industrial price ratios were more likely to pressure policy makers to deregulate.

\section{kWh Prices}

While the ratio of consumer to industrial electricity prices is likely to play a significant part in a state's propensity to adopt electric deregulation, we argue the absolute price of electricity per kWh for residential, commercial, and industrial users is also likely to play a significant role in deregulation (Andrews 2000; Steiner 2004). Electric rates vary considerably across the states and as the actual overall rates increase we argue the propensity of a state to deregulate will increase. ${ }^{6}$ Moreover, building on our earlier discussion of the relative power of industrial groups, we expect elevated costs in the industrial sector to have the most substantially impact on deregulation. In order to fully examine the influence of absolute prices, we measure and test in separate models the price per $\mathrm{kWh}$ as the average for all consumers and also by sector (residential, commercial, and industrial).

\section{Public Utility Commissions}

Public Utility Commissions (PUCs) play a critical role in the decision of a state to adopt electric deregulation. As noted by Ka and Teske (2002), the support of the PUC for a deregulatory plan is critical for its success. With this in mind, we differentiate between elected and appointed state public utility commissions. As Teske (2004) suggests, elected commissioners are likely to be more responsive to consumers' short-term interests than those who are appointed. Therefore we hypothesize elected commissioners would be more likely to support deregulation on the basis that it promised lower electricity rates for consumers.

\section{Legislative Professionalism}

Of the institutional forces, numerous scholars have noted the impact of legislative professionalism on policy innovation (Berry 1979; Joskow 1997; Ka and Teske 2002; King 2000; 
Mooney 1994; Ringquist and Garand 1999; Stevenson and Penn 1995). As suggested by previous research, we maintain more professional legislatures are more likely to have the resources, expertise, and ability to actively explore (and ultimately adopt) policy innovations in comparison to less professionalized legislatures.

In order to test this hypothesis, we use King's (2000) measure of legislative professionalism for each state. King uses a modified version of Squire's (1992) method for measuring state legislature professionalism, relative to Congress. King uses three comparison points for state legislatures and Congress - compensation, days in session, expenditures for service and operations (minus legislator compensation) per legislator (in constant dollars). King's modification lies with the third component and substitutes expenditures for staff and support members instead of Squire's measure of the number of staff members. This modification supports Teske's (1991) finding in his analysis of the telecommunications industry that regulatory budgets are an effective measure of institutional power. Larger budgets allow for larger staffs, which leads to more fully developed analyses of regulatory choices (Teske 1991).

\section{State Partisanship}

While previous scholars (Altman 1997; Ka and Teske 2002; Lester 1983; Ringquist 1993; Teske 2004) have noted the significant role of legislative professionalism as a predictor of state energy policy variation, few have addressed the possible role of partisanship. Considering the general preference of the Republican Party for less government regulation and their stronger ties with business and industry groups, we hypothesize state governments controlled by the Republican Party will be more likely to adopt electric deregulation policy. This hypothesis is tested using a trichotomous variable coded -1 for Democratic controlled state governments, 0 for divided state governments, and 1 for Republican controlled state governments.

\section{Interest Group Pressures}

While state legislatures ultimately adopt or reject electric deregulation, they receive pressure on this issue from a range of interest groups. Since it is particularly difficult to determine interest group pressures on the issue of energy deregulation in a particular state, we utilize two proxies for measuring this concept. The first measure replicates the analyses of Ka and Teske (2002) which utilize as a proxy for industrial interest group influence the work force employed in manufacturing divided by the total state work force. Ka and Teske (2002) adopt this measure based on the idea that manufacturing interest groups are most likely to be well organized and have incentives to participate actively in the legislative process by offering information and resources to elected officials in support of deregulation. 
As a second and unique proxy for the influence and interest of the electric industry for deregulation in each state, we measure the actual number of major electric power companies (as determined by FERC in 1996). Our theory is that the greater the number of major power companies in a state the more potential competition within that state; thus, the greater likelihood for favoring deregulation of the electric industry.

\section{Regional Diffusion}

Regional diffusion explanations are commonplace in the regulatory literature (Berry and Berry 1990; Gray 1973; Newmark 2002; Teske 2004; Walker 1969) and provide ample rationale for an analysis of regional diffusion. As Newmark (2002) notes, "the strength of diffusion studies lie in their predictive ability to determine what factors, whether organization, geographic, or internal, will lead to program or policy adoption” (Newmark, 161). Teske (2004) argues as one state adopts a new policy, the expectation is that other surrounding states are more likely to adopt the policy.

Walker (1969) finds that states adopt policies by analogy and through policy use in neighboring states. He finds that inertia within a state can be overcome when proponents of change can point to successful implementation in other states. Berry and Berry (1990) agree, and note,

policy adoptions for nearby states provide a critical resource (information) for overcoming an obstacle (uncertainly) to innovation ... with a policy unpopular to the electorate, it should be easier for politicians to justify its adoption to voters if it has first been adopted by nearby states (Berry and Berry, 400)

Walker posits that once policies are accepted among many states, that policy may become recognized as a legitimate state responsibility for non-innovating states. Also, Walker believes the growth of intergovernmental organizations, such as the Council of State Governments (CSG), allowed for greater contact among state leaders and increased the spread of information (Walker, 1969). These intergovernmental organizations provide sources of new information and policy cues for decision-makers from across the United States. Gray (1973) also found that diffusion typically occurred through the interaction of policy innovators from certain states and decision-makers from other states. Further, Gray (1973) finds that innovativeness is, for the most part, issue-specific. ${ }^{7}$

Building on the strong evidence of previous scholars regarding the significant impact of regional diffusion on the probability of states adopting new policies, we include in our model of energy policy innovation a measure of regional diffusion. This variable is measured simply as a ratio of the surrounding states that have adopted deregulation each year to the total number of surrounding states (Berry and 
Berry, 1990). After one state deregulates its electricity market, our expectation is that other surrounding states will be more likely to deregulate.

\section{$\underline{\text { Data and Methods }}$}

We follow Berry and Berry (1990) in using event history analysis (EHA), a pooled time-series cross-sectional model, to determine whether diffusion played a role in triggering deregulation in specific states. Discrete event history analysis focuses on the risk that the individual units (in this case, states) have of "experiencing the event" at a particular time (Berry and Berry, 397). This model accounts for both regional and internal influences and predicts policy innovation for each state based on that state's characteristics, rather than focusing on a single-set of characteristics from the initial time the policy innovation was adopted in the first state, and can predict whether a particular state will or will not innovate (Allison 1984; Berry and Berry 1990; Box-Steffensmeier and Jones 2004; Hosmer and Lemeshow 1999).

The starting point for our analysis is 1996, since this is the year which states started to adopt deregulatory policy innovations, and the end point is 2001, since the momentum behind restructuring froze as a result of the events which unfolded in California. Because of the censoring of event history data, all forty-seven states which are included in our analysis appear in the 1996 "risk set", only fortythree states reappear in the 1997 risk set, since four states that adopted deregulatory policy innovation in 1996 are no longer observed in the "risk set”; and so on until 2001 (See Figure 1). ${ }^{8}$

While the actual implementation of electric deregulation has varied considerably by state, the actual deregulatory bills have been quite similar across states. Thus, we use a zero-one binary variable to measure the decision to adopt energy deregulation policies (See Appendix A for list of states and the year which they adopted energy deregulation policies). We argue this dichotomous variable captures the variance as reliably as other studies of state innovations which similarly employ an event history model (Berry and Berry 1990; Teske 2004). Ultimately the EHM Base Model of Policy Innovation which we estimate is as follows: 
Y $\left(\right.$ Electric Deregulation 0/1) $=\mathcal{B}_{0}+\mathcal{B}_{1}$ Industrial/Residential Price Ratio $+\mathcal{B}_{2} \mathrm{kWh}$ Prices $+\mathcal{B}_{3}$ Elected Public Utility Commission $+\mathcal{B}_{4}$ Legislative Professionalism $+\mathcal{B}_{5}$ Republican Party Control + $\mathcal{B}_{6}$ Proportion of Population in Manufacturing $+\mathcal{B}_{7}$ Number of Major Electric Companies + $\mathcal{B}_{8}$ Proportion of Nearby De-Regulated States

\section{$\underline{\text { Analyses and Results }}$}

The results of our base model of state policy innovation are reported in Table $1 .^{9}$ The over all model is quite strong with a Wald Chi of $60.43(\mathrm{p}<.001)$. Of the eight explanatory factors four meet the traditional standards for statistical significance. While the remaining variables do not meet the traditional standards of statistical significance their coefficients are in the hypothesized direction, except for the variables Industrial/Residential Price Ratio and Proportion of Population in Manufacturing.

Among the four statistically significant factors in our model of electricity restructuring, the results indicate price per $\mathrm{kWh}$ is most significant. As hypothesized, states which pay higher prices per kWh are more likely to restructure than those with relatively lower prices. More specifically, our model indicates a ten cent increase in a state's price per kWh increases their probability of adopting electricity restructuring policies by twenty-three percent. Considering the price per kWh varied throughout our study from less than four cents to over 11 cents, price per kWh is clearly a substantial factor in understanding electricity restructuring. Undoubtedly high energy prices provide legislators with strong incentives and the motivation necessary to examine and ultimately adopt energy policies aimed at alleviating these constituent expenditures. Of particular interest, we note when price per kWh for residential, commercial and industrial sectors were included individually, the results indicated no single industry had a significantly greater impact on policy adoption.

While the results of our analyses for price per $\mathrm{kWh}$ fall in line with our hypotheses, the results for Industrial/Residential Price Ratio is significant but in the opposite direction as we hypothesized. Specifically, we find states where the difference between residential and industrial rates are greatest are the least likely to adopt deregulation. Considering these results we follow the arguments of Teske (1991) which suggest high industrial/residential price ratios in a state are perhaps indicative of the lack of influence industrial interests maintain in these states. If the industrial interests in a state do not have the 
ability to attain favorable industrial/residential price ratios they likely lack the influence, resources, or ability to initiate electricity restructuring.

As with previous analyses of policy innovation, we also find legislative professionalism has a positive and statistically significant impact on the probability of a state adopting electricity restructuring. As noted above, more professional legislatures are more likely to have the resources, time, expertise, and ability to actively explore (and ultimately adopt) policy innovations in comparison to less professionalized legislatures. Specifically, we find a one standard deviation increase in a state's legislative professionalism increases their probability of restructuring by forty-five percent. The ironic issue here, which we address in greater detail below, is the most sophisticated and resourceful state legislatures were the most aggressive in adopting a policy which many perceive to be a complete disaster.

Partisan control of state government is also found to significantly influence the probability of a state adopting electricity deregulation. In particular, we find for each additional branch of state government controlled by the Republican Party there is a twenty-six percent increase in the probability of the state adopting electricity deregulation policies. While previous research has ignored the role of state partisanship with regard to policy innovation in this domain, our results indicate the ideological and constituent interests of the Republican Party clearly primes them for policy innovation in this domain.

While the additional factors included in our EHM Base model failed to attain traditional levels of statistical significance and therefore will not be discussed further in this section, the regional diffusion variable (proportion of nearby deregulated states) is of particular theoretical interests for this work and warrants further analysis. As noted above, regional diffusion explanations are commonplace in the regulatory literature. As Walker (1969) originally argued, states adopt policies by analogy and through policy use in neighboring states, once a policy is accepted across several states that policy is likely to become recognized as a legitimate state responsibility for non-innovating states.

Considering the strong theoretical underpinnings of this factor, we were clearly perplexed by our lack of statistically significant findings for the regional diffusion factor. With this in mind we reexamined our based model with a particular focus on our policy diffusion variable. Interestingly, we found policy diffusion was highly correlated $(.524 \mathrm{p}<.001)$ with price per $\mathrm{kWh}$. Considering these results and the clear potential for multicollinearity between these two variables, we retested the model after dropping the price per kWh variable. As expected, the regional diffusion variable in the reduced model was statistically significant and in the hypothesized direction. Consequently, we contend regional diffusion plays at least a nominal role in a state's adoption of electricity restructuring. 


\section{Conclusion}

The broad purpose of this research was to provide an improved understanding of general state policy innovation with a focus on the role of policy diffusion. More narrowly we aimed to develop and test a model of policy innovation which examined the factors that influence the probability of a state restructuring its electric utility policies. While the model which we developed was built on the work of numerous scholars who have addressed state policy innovations, we leaned particularly on the work of Ka and Teske (2002). In addition to several traditional factors, we also included in our model several unique and innovative factors theoretically related to electric policy innovation. Most notably, distinct from previous analyses we included in our model the actual price per kWh, the partisanship of the state government, the number of major power suppliers within the state, and a measure of regional diffusion.

The results of our model of electric restructuring generally support our hypotheses and more broadly the literature regarding policy innovation. Our most important findings are linked to the new factors we examined which previous scholars in this policy domain have overlooked. First, the significant and substantial findings for energy prices were not surprising but insightful. States where constituents pay the highest energy prices are the states most likely to examine and ultimately adopt policy innovations. Legislatures in states where consumers enjoy relatively low energy prices have significantly fewer incentives to look for alternatives to their current energy policies, while states with high energy costs have significant and tangible reasons to search for alternatives. In line with these findings our analysis also revealed that states under Republican control were most likely to adopt electric restructuring. This finding supports our hypothesis which argued Republican controlled governments would be more likely to adopt policies which lead to deregulation and smaller government and also supported their key constituencies. While numerous scholars have focused on the Republican Party's focus in recent years on policies related to social conservatism, these findings suggests business constituencies and the goal of a more limited government continue to significantly influence their policy choices.

Finally, we note it is interesting that a policy innovation which has failed so miserably was most likely to be adopted by the most professional (sophisticated) legislatures. Two observations are in order here. First, only in retrospect do we know that electricity deregulation has generally been considered a failure. Other earlier state deregulation efforts in telecommunications and natural gas have been generally regarded as successes so we might assume that the professional legislatures (and more importantly their staffs) would have used the analogous successful deregulatory efforts as precedent. More important we think is the policy atmosphere surrounding electrical deregulation. The policy entrepreneur driving deregulation was the energy trading industry led by the now defunct Enron Corporation. Remembering 
the economic climate of the mid-nineties where fortunes were being made on a "new economy" of trading ephemeral commodities like energy futures and margins, it is possible to expect that the most sophisticated legislators were seduced into thinking that they were on the cutting edge of this new economic era. It would have been considered so "old economy" to hold on to those quaint sixty year old regulatory regimes where entrepreneurs were handcuffed by antiquated utility commissions. So with that understanding, it is perhaps not so surprising that the most sophisticated legislatures were the most prone to advocate such a risky and ultimately failed policy innovation.

In summary, the results of our analysis suggest that economic interests continue to represent a key factor in understanding the policy choices of state legislatures. States which faced high energy costs were most likely to look for opportunities to reduce those costs. Furthermore, states legislatures with the greatest resources and expertise were quickest to explore and adopt policy innovations in response to their high energy costs. States where the general policy preferences of those in power favored deregulation were also more likely to restructure. 


\section{$\underline{\text { References }}$}

Adams, Paul. Lights go dim for electricity deregulation. Chicago Tribune, April 2, 2006. www.chaicagotribune.com/business/chi-060402021apr02,1,6625715.story

Administration, Energy Information. Electricity Prices in a Competitive Market: Marginal Cost Pricing of Generation Services and Financial Status of Electric Utilities

A Preliminary Analysis Through 2015 Energy Information Administration, 1997 [cited. Available from http://tonto.eia.doe.gov/FTPROOT/electricity/0614.pdf.

Administration, Energy Information. 2005. Status of State Electricity Restructuring Activity 2003 [cited February 2005 2005]. Available from http://www.eia.doe.gov/cneaf/electricity/chg_str/restructure.pdf.

Allison, Paul D. 1984. Event History Analysis: Regression for Longitudinal Data, Quantitative Applications in the Social Sciences. Beverly Hills, CA: SAGE Publications, Inc.

Altman, J. 1997. The Politics of Electric Utility Regulation: Explaining Energy Efficiency Policy in the States. Ph.D. Dissertation, University of Tennessee, Knoxville.

Ando, A. W., and K. Palmer. 1998. Getting on the Map: The Political Economy of State-Level Electricity Restructuring: Resources for the Future.

Andrews, C. 2000. Diffusion Pathways for Electricity Regulation. Publius: The Journal of Federalism 30 (3):17-34.

Berry, Frances Stokes, and William D. Berry. 1990. State Lottery Adoptions as Policy Innovations: An Event History Analysis. The American Political Science Review 84 (2):394-415.

Berry, William D. 1979. Utility Regulation in the States: The Policy Effects of Professionalism and Salience to the Consumer. American Journal of Political Science 23 (2):263-277.

Borenstein, Severin. 2002. The Trouble with Electricity Markets: Understanding California's Restructuring Disaster. The Journal of Economic Perspectives 16 (1):191-211.

Borenstein, Severin, and James Bushnell. 2000. Electricity Restructuring: Deregulation or Reregulation? Regulation 23 (2):46-52.

Box-Steffensmeier, Janet M., and Bradfor S. Jones. 2004. Event History Modeling: A Guide for Social Scientists. New York: Cambridge Press.

Chubb, John E. 1983. Interest Groups and The Bureaucracy: The Politics of Energy. California: Stanford University Press.

Freese, Barbara. 2003. Coal: A Human History. Cambridge, MA: Perseus Publishing.

Gormley, William T. 1983. Policy, Politics, and Public Utility Regulation. American Journal of Political Science 27 (1):86-105.

Gray, Virginia. 1973. Innovation in the States: A Diffusion Study. The American Political Science Review 67 (4):1174-1185.

Hirst, Eric. 2005. The California Electricity Crisis: Lessons for Other States Edison Electric Institute, 2001 [cited March 2005 2005]. Available from http://www.heartland.org/pdf/12529.pdf.

Hosmer, David W., and Stanley Lemeshow. 1999. Applied Survival Analysis: Regression Modeling of Time to Event Data. New York: John Wiley and Sons, Inc.

Irvin, Samuel, J. III, Interview with author, January 27, 2006. 
Joskow, P., ed. 2000. Deregulation and Regulatory Reform in the US Electric Power Sector. Edited by P. a. Winston, Deregulation of Network Industries: What's Next. Washington, DC: Brookings Institution Press.

Joskow, Paul L. 1997. Restructuring, Competition, and Regulatory Reform in the U.S. Electricity Sector. The Journal of Economic Perspectives 11 (3):119-138.

Ka, Sangjoon, and Paul Teske. 2002. Ideology and Professionalism: Electricity Regulation and Deregulation Over Time in the American States. American Politics Research 30 (3):323-343.

King, James D. 2000. Changes in Professionalism in U.S. State Legislatures. Legislative Studies Quarterly 25 (2):327-343.

Lester, James. 1983. Hazardous Waste Politics and Public Policy: A Comparative State Analysis. Western Political Quarterly 36:258-285.

Mooney, Chris. 1994. Measuring U.S. State Legislative Professionalism: An Evaluation of Five Indices. State and Local Government Review 26:70-78.

Moyer, R. Charles. 1993. The Impending Restructuring of the Electric Utility Industry: Causes and Consequences. Business Economics:40-44.

Newmark, Adam. 2002. An Integrated Approach to Policy Transfer and Diffusion. The Review of Policy Research 19 (2):151-178.

Ringquist, Evan. 1993. Does Regulation Matter? Evaluating the Effects of State Air Pollution Programs. Journal of Politics 55:1022-1045.

Ringquist, Evan, and James Garand. 1999. Policy Change in the American States. In American State and Local Politics, edited by R. Weber and P. Brace. New York: Chatham House.

Rosenbaum, Walter A. 2003. Environmental Politics and Policy. 5 ed. Washington D.C: CQ Press.

Squire, Peverill. 1992. Legislative Professionalization and Membership Diversity in State Legislatures. Legislative Studies Quarterly 17:69-79.

Steiner, F. 2004. The Market Response to Restructuring: A Behavioral Model. Journal of Regulatory Economics 25 (1):59-80.

Stevenson, Rodney E., and David W. Penn. 1995. Discretionary Evolution: Restructuring the Electric Utility Industry. Land Economics 71 (3):354-365.

Teske, Paul. 1991. Interests and Institutions in State Regulation. American Journal of Political Science 35 (1):139-154.

Teske, Paul. 2004. Regulation in the States. Washington, DC: Brookings Institution.

Thomas, Clive S., and Ronald J. Hrebenar. 2004. Politics in the American States: A Comparative Analysis. Edited by V. Gray and R. L. Hanson. Vol. 8. Washington D.C.: CQ Press.

Timney, Mary M. 2005. Power for the People: Protecting States' Energy Policy Interests in an Era of Deregulation. Armonk, New York: M.E. Sharpe.

Walker, Jack L. 1969. The Diffusion of Innovations among the American States. The American Political Science Review 63 (3):880-899.

White, M. 1996. Power Struggles: Explaining Deregulatory Reforms in Electricity Markets: Brookings Papers on Economic Activity: Microeconomics. 


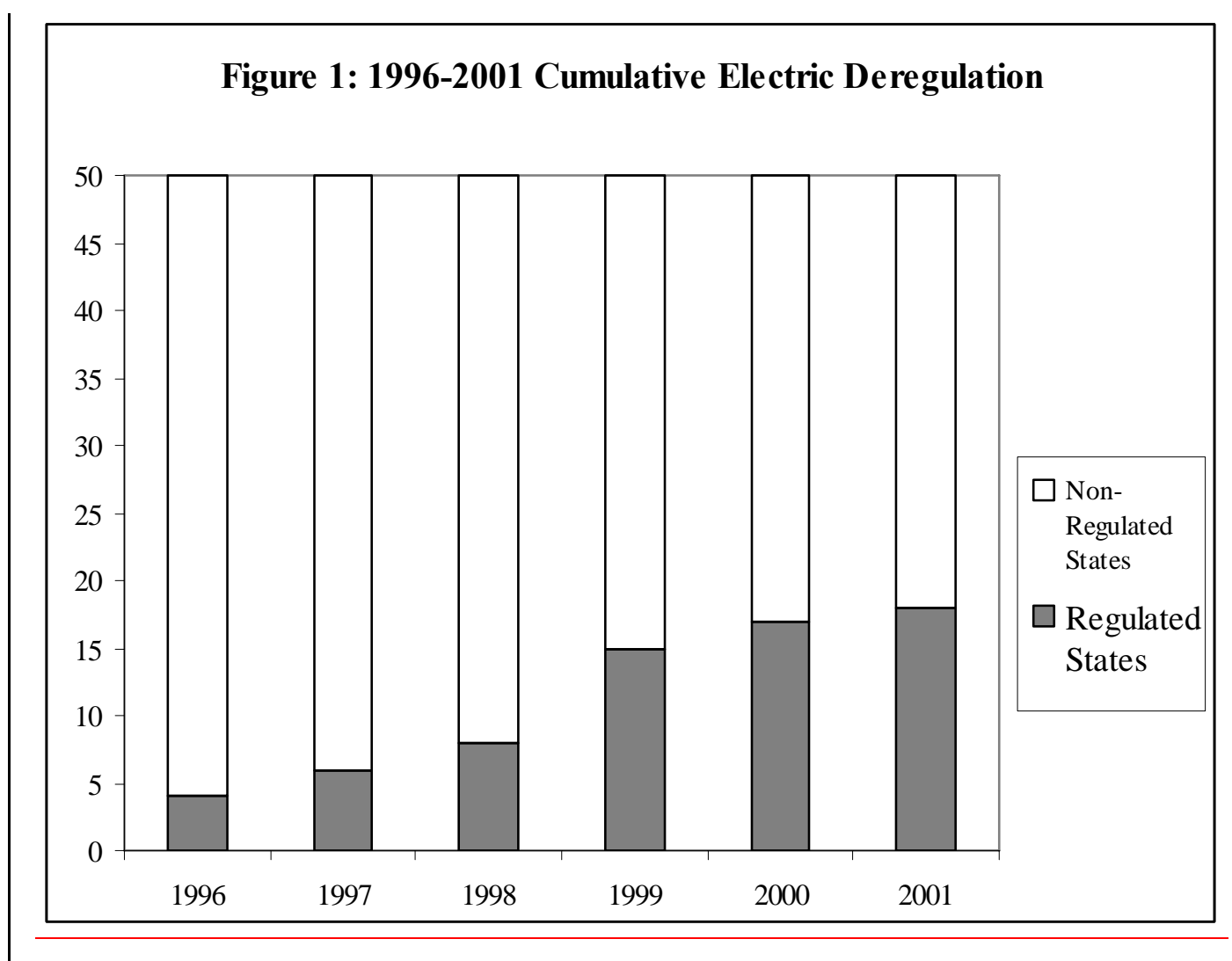


Table 1: Event History Model of Electricity Deregulation 1996-2001

\begin{tabular}{|l|c|c|c|c|}
\hline Explanatory Factors & Theory & Coefficient & $\begin{array}{c}\text { Robust Standard } \\
\text { Errors }\end{array}$ & Z Score \\
\hline kWh Prices** & + & 0.211 & 0.053 & 3.94 \\
\hline Industrial/Residential Price Ratio* & + & -0.019 & 0.011 & -1.82 \\
\hline Elected Public Utility Commission & + & 0.437 & 1.265 & 0.35 \\
\hline Legislative Professionalism* & + & 3.492 & 1.897 & 1.84 \\
\hline Republican Party Control* & + & 0.230 & 0.139 & 1.65 \\
\hline Proportion of Population in Manufacturing & + & -5.446 & 5.495 & -0.99 \\
\hline Number of Major Electric Companies & + & 0.138 & 0.134 & 1.03 \\
\hline Proportion of Nearby De-Regulated States & + & 0.238 & 0.282 & 0.84 \\
\hline
\end{tabular}

${ }^{*} \mathrm{p}<.05 ;{ }^{* *} \mathrm{p}<.01$

\section{Summary Statistics}

Wald Chi-2 $=60.43$

Pseudo Log Likelihood $=-38.709$

$\mathrm{N}=185$ 


\section{Appendix A: Year States Adopted Energy Restructuring Policies}

\begin{tabular}{|c|c|}
\hline State & $\begin{array}{l}\text { Year Energy Restructuring Policies } \\
\text { Adopted }\end{array}$ \\
\hline California & 1996 \\
\hline New York & 1996 \\
\hline Pennsylvania & 1996 \\
\hline Rhode Island & 1996 \\
\hline Maine & 1997 \\
\hline Massachusetts & 1997 \\
\hline Arizona & 1998 \\
\hline Connecticut & 1998 \\
\hline Delaware & 1999 \\
\hline Illinois & 1999 \\
\hline Maryland & 1999 \\
\hline New Jersey. & 1999 \\
\hline Ohio & 1999 \\
\hline Texas & 1999 \\
\hline Virginia & 1999 \\
\hline Michigan & 2000 \\
\hline New Hampshire & 2000 \\
\hline Oregon & 2001 \\
\hline \multicolumn{2}{|c|}{ States which did not Restructure Energy Policies } \\
\hline Alabama & Nevada \\
\hline Arkansas & New Mexico \\
\hline Colorado & North Carolina \\
\hline Florida & North Dakota \\
\hline Georgia & Oklahoma \\
\hline Idaho & South Carolina \\
\hline Indiana & South Dakota \\
\hline Iowa & Tennessee \\
\hline Kansas & Utah \\
\hline Kentucky & Vermont \\
\hline Louisiana & Washington \\
\hline Minnesota & West Virginia \\
\hline Mississippi & Wisconsin \\
\hline Missouri & Wyoming \\
\hline Montana & \\
\hline
\end{tabular}


i The authors would like to acknowledge Mr. Jonathan Kanipe, graduate research assistant, for his significant contribution to this project.

2 Some commentators confuse "restructuring" of electric utilities with "deregulating" the utilities. The providers of electric services are still carefully regulated by state commissions. Restructuring refers to the type of market within which the regulated utilities operate. Rather than a monopolized market required prior to the 1992 EPAct, the restructured market allowed for companies offering retail competition with regulated markets.

3 Indicative of this lack of interest in restructuring on the states' political agendas in the US Energy Information Administration's web site which suspended its comprehensive tracking of restructuring activity across the states in 2001. Further, Commissioner Samuel J. Ervin III who is a Commissioner on the NC Utility Commission and a member of the National Association of Utility Regulatory Commissions indicated to the author that further restructuring activity is not anticipated across the states in the foreseeable future. (Irvin, January 27, 2006).

4 Joskow (1997) defines the price gap as that between those who receive "unbundled" prices (customers only responsible to pay for the transmission and distribution) and those that pay bundled prices (i.e. those with the cost of generation services included in the costs) (Joskow, 125, 1997). For a full understanding of the price gap, one must appreciate the direct correlation between kilowatt hour prices and sunk costs. Sunk costs are those associated with construction of transmission systems and new generation facilities. More explicitly, Joskow (1997) finds that sunk costs represent nuclear power investments and expensive contracts that utilities were required to sign under PURPA requirements (Joskow, 1997, 127). Electricity producers must generate at maximum capacity (i.e. the amount necessary for the highest daily demand of the year) at all times, which creates high prices for peak generation. When the high cost of nuclear generation is added to this equation, it is understandable that the cost becomes higher than for conventional electricity producers. As a result, states with heavy investment in nuclear energy would also typically be on the higher end of the price gap and adopt policies that would lower prices.

Several authors link price disparity to sunk costs (Borenstein and Bushnell, 2000; Borenstein, 2002; Joskow, 1997; and Moyer, 1993). Borenstein and Bushnell find that states without sunk costs are less likely to restructure (Borenstein and Bushnell, 2000, 47) and posit that prices fell in California as a result of paying off sunk investments in nuclear power plants and the expiration of expensive PURPA contracts, not as a result of deregulation (Borenstein and Bushnell, 51).

5 For the period of our analysis (1996-2001) the mean Industrial/Residential kWH Price ratio is .58 with a standard deviation of .07 and a maximum of .95 (Nevada 2001) and a minimum of .38 (Montana 2000).

6 For the period of our analysis (1996-2001) the mean price per kWH for residential consumers was 7.8 cents (Min 5.0థ and Max 14.0థ), for commercial users the mean was 6.8 cents (Min 4.2 $₫$ and Max 12.5థ), and for industrial users the mean was 4.6 cents (Min $2.5 \$$ and $9.8 \$$ ).

7 She did not find a strong correlation of policy innovation for the policy fields studied, instead, innovativeness was time and issue specific (Gray, 1185).

8 Our data set does not include 3 states (Hawaii, Alaska, and Nebraska). Hawaii and Alaska were dropped from the analysis for theoretical reasons. They are not part of the continental United States and therefore are not subject to regional diffusion, a key factor of our analysis. They also have relatively extreme climates and unique economies which likely make the factors influencing energy policy in their state legislatures quite unique. An additional analysis was conducted with these two states and the results of this analysis produced coefficients and levels of significance nearly identical to those reported. The state of Nebraska was dropped from the analysis for purely methodological reasons. Due to Nebraska's non-partisan legislature, legislative partisanship data can not be collected.

9 The EHA model reported in Table 1 and discussed throughout this section utilizes a Cox Proportional Hazard's Model with Robust Standard Errors. For an excellent and straightforward discussion of the steps employed for interpreting the coefficients of a Cox Proportional Hazard's Model, see the discussion put forward by David W. Hosmer, Jr. and Stanley Lemeshow in Applied Survival Analysis: Regression Modeling of Time to Event Data (1999). 